\title{
Innovation Economics Development of the Region within the Frames of Cluster
}

Tsertseil J.S.

\author{
Kazan Federal University, Institute of Management, Economics and Finance, Kazan, 420008, Russia
}

Email: zerzeil8811@mail.ru

\author{
Doi:10.5901/mjss.2015.v6n1s3p183
}

\begin{abstract}
In the context of economic ties globalization the economic actors in the certain region play a role of the agents participating in improving performance, obtaining positive dynamics of regions development and new job formation. Innovative development will make possible to increase competitive advantage both of the regions and of the country as a whole. The Republic of Tatarstan innovative development is based on maximization of inner potential in economic development of the territory as a result of competitive advantage intensification within the frames of the effective market institutions, the state support in the field of research and technology innovations, formation of techno parks and technology incubators. The program of the region innovative development implies clusters forming and further evolving on the basis of petrochemical sector enterprises, educational and research institutes located on the territory of Tatarstan.
\end{abstract}

Keywords: innovation policy, intellectual capital, cluster, labor costs, productive efficiency.

\section{Introduction Method}

Most studies show that differences in profitability within industries are much more important than differences between industries. The key to a resource-based approach to strategy formulation is understanding the relationships between resources, capabilities, competitive advantage, and profitability - in particular, an understanding of mechanism through which competitive advantage can be sustained over time. [9] In order to obtain competitive advantage, companies invest more and more capital in technology. Therefore, capital cost is more and more significant proportion in total cost. [8] But breakthrough innovations provide the innovator a significant comparative advantage that can often be sustained through time. These small innovations have a cumulative effect on resource advantage and, hence, on efficiency and effectiveness. [15] Intellectual capital disclosure comprises three categories: human capital, structural capital, relational capital. Human capital captures the knowledge, professional skills, experience and innovativeness of employees within an organization. Structural capital consisits of the structures and processes employees develop and deploy in order to be productive, effective and innovative. [4] Human capital is considered a strong complement to investment in physical capital. Human factors are important contributors to the increase in productivity and innovation via know-how diffusion. [5]

Lent defined innovation as a complex multiphased activity, where an artefact moves from initiation to adoption and implementation within a unit of adoption. [12] Innovation is an iterative process initiated by the perception of a new market and new service opportunity for a technology-based invention, which leads to development. Innovation strategy basically focuses on radical and incremental innivations. Only radical innovation could lead to significant growth. [11]

It has been suggested that in the information age a larger and larger portion of a company's economic value is associated with it is intanjible assets, intellectual property often being the most important. [3] Innovation process is based on knowledges. Knowledge is the outcome of learning. Knowledge can manifest itself in changes in cognitions or behavior. The knowledge can be explicit or tacit and difficult to articulate. The knowledge includes both knowledge in the sense of a stock and knowing in the sense of a process. [1]

Innovation process influences on the quality of tne product due to value based category. In this view quality is jointly determined by the product's conformance to specifications and the price (cost) of attaining that product. [13]

The results of innovative process could decline the weighted average cost of the capital (WACC) in the future. At the same time WACC is influenced on the economic value added (EVA). [14] Profitability of the company is based on value added strategy and value added growth. The value added strategies and growth in value are depended on company size, growth and corporate strategy. The highest correlation is between turnover and scale of production capacity. (.972 at $p<0.01)$. [6]

As a form of regional economy industrial enterprises and services integration, the industrial district is formed due to the scale effect increase of enterprise and regional market. The business basic competences include: human capital, 
scientific research, informational capital. [2]

At present the innovative potential on the territory of the Republic has been formed of the base of petrochemical sector enterprises what is reproduced in Table 1. The process of identifiable (tangible) assets value creation in innovative economy makes no problem and is identified with such categories as efficiency (profitability) and capital cost. The indicators of performance, operating profitability of capital intensive manufacture in an innovative sector are, on the one side, linked with such categories as capital assets depreciation reserve ratio and coefficient of renewal, retirement rate, capital-labor ratio and workforce productivity. Therefore, the main share of enterprise assets in the given sector of economics makes capital assets within the structure of non-circulating assets.

On the other hand, nowadays competitive advantage of industrial enterprises become more and more dependent rather on the senior management and staff's capacities for elaboration and implementation of product, technology and managerial innovations than on disposable capital resource level and material assets. Introduction of the abovementioned innovations appears to be the background of the economic growth. But the process of intangible assets value creation is quite complicated. Key contribution to companies' competitive advantage provision is made by their innovative potential which, in its turn, is to a greater extent dependent on knowledge-consumptive business environment. The given conditions to the fullest extent possible reveal themselves in a cluster both on micro and meso-level and on macro-level as well. So, M.Porter has formulated the aftereffect of the regional and local business environment upon a company's competitive ability according to the following trends: factorial terms, terms of demand, the character and intensity of local competition, availability of relative and accompanying sectors. Geographical proximity and combination of manufacturing companies, customers and suppliers intensify pressure upon the process of innovations implementation.

Macroeconomic indicators of innovation policy in the Republic of Tatarstan within the period of 2008-2010.

\section{Table 1}

\begin{tabular}{|c|c|c|c|}
\hline Indicators & 2008 & 2009 & 2010 \\
\hline Persons with higher vocational education aged 20-29 in total population per 1000 people & 173,7 & 173,7 & 173,7 \\
\hline Persons with post graduate education aged $25-64$ in total population per 1000 people & 3 & 3 & 3 \\
\hline R\&D spending in Gross Regional Product, \% & 0,2 & 0,2 & 0,2 \\
\hline Public expenditures for education in Gross Regional Product, \% & 3,2 & 3,2 & 3,4 \\
\hline Enterprises' expenditures for innovations in the amount of shipped goods of their own production, $\%$ & 2,6 & 1 & 1,4 \\
\hline
\end{tabular}

\section{Theory}

The following factors of economic growth can be associated with innovation economics:

- capital quantity with quality;

- labour quantity with quality;

- natural resources quantity with quality;

- growth of technology (embodied in physical capital, unembodied in physical capital)

- education and human capital ameliorating the quality of labour. [10]

The following industry-based characteristics in the perception of various innovations stimulation measures can be distinguished:

- for chemical and consumer goods industries: budgetary co-funding of innovation projects;

- for iron and steel enterprises: introduction of conventional tax allowances according to the expenditures for research and development;

- for enterprises engaged in civil engineering: investment premium.

Characteristics of economic system innovation development (List of basic foundations and their content):

- Availability of objective critical situations in cycles: various types of crises depending on factors of inner and outer environment are taken into consideration;

- Methodology of studies: systemic approach considered in dynamics in accordance with objective laws of the system development;

- Object properties: technical including scientific research, economical, regional (territorial) in the light of social interests;

- Development planning and projections: alternative (multi-script) prognosis based on the patterns of economic system cyclic development and theory of crises; 
- Prognoses intended use: elaboration of strategic priorities and ensuring their implementation on the grounds of financial and economic approaches;

- The subject matter of managerial activities: forecasting of crisis processes manifestation;

- External environment: markets: of innovations, of capital (investments), of personnel, of products and services. Innovation management problems:

- determination of economic entities' innovation potential in order to minimize resources investment and maximize the results obtained;

- evaluation of innovation processes influence on the population's demands potential and structural changes;

- compliance of the new processes developers' innovation potential with innovation managers' competence requirements;

- determination of industrial innovation's moral depreciation signs and organization of facilities for secondary use of materials, energy, information and staffing support.

In a broader context, the long-wave economic model is based on such categories as rate of labour productiveness increment, capital employment ratio, profit return and absorbed expenses. (1), (2), (3) . The statistical analysis of temporal series and empirical regularities data selection helped N.D. Kondratiev to substantiate the theory of long wave's endogenous character. So, for instance, advance in technology is triggered by the demands of the certain industry and arrangement of such conditions which stipulate the possibility of the inventions application. Each consecutive stage is a result of cumulative processes collected during the previous phase. The innovation theory developed by Austrian economist, Joseph Alois Schumpeter, is one of such long-wave theories. In Schumpeter's theory, the ability and initiative of enterpreneurs, drawing upon the discoveries of scientists and inventors, create entirely new opportunities for investment, growth and employment. The profits made from these innovations are then the decisive impulse for new surges of growth, acting as signal to swarms of imitators. [7]

(1) $d y / d x=-a(y-b k)$;

(2) $d k / d t=-\beta(k-g p)$;

(3) $p=y-R$, where

$\mathrm{y}$-rate of labour productiveness increment,

$a, b, \beta, g$-composition ratios,

$\mathrm{k}$ - rate of capital employment ratio increment,

$\mathrm{p}$ - rate of profit return increment,

$\mathrm{R}$ - rate of absorbed expenses increment.

All of these categories can be improved simultaneously in case of innovation pattern for economy development. That is why the function of production formulated as (4) can be written in the following way (5):

(4) $\mathrm{Q} 1=\mathrm{F}(\mathrm{L}, \mathrm{K})$

(5) $\mathrm{Q} 2=\mathrm{F}(\mathrm{L}, \mathrm{K}, \mathrm{U})$,

$\mathrm{Q}$ - total of output;

$\mathrm{L}$ - the amount of labour for the given output;

$\mathrm{K}$ - cost of capital invested in the given production;

$\mathrm{U}$ - cost of intellectual capital invested in the given volume of production.

Application of intellectual capital in productive activity requires both capital investments and labor costs. Therefore, the value of intellectual capital can be formulated by means of the following dependence (6), (7):

(6) $\mathrm{U}=\mathrm{Fu}(\mathrm{Lu}, \mathrm{Ku})$,

(7) $\mathrm{Q} 3=\mathrm{F}(\mathrm{L}, \mathrm{K}, \mathrm{Fu}(\mathrm{Lu}, \mathrm{Ku}))$, where

$\mathrm{Lu}$ - labor costs for creating a new product, service or target;

$\mathrm{Ku}-$ expenses on research and technological development expressed in the statement of assets and liabilities.

\section{Results}

In an effort to raise the effectiveness of innovation activities based on the current knowledge an enterprise produces the assemblage of innovations (related to technology, organization and management, marketing and resources) and ensures efficient production of innovative items. Thus, the enterprise generates the dynamic growth of intellectual resources and intellectual assets one part of which is recognized on the balance sheet within intangible assets and the other part - as goodwill. If the investment is being made and capitalizing R\&D costs is a visible signal that the organization sees R\&D as a bridge to the future, not as a cost center that needs to be limited or reined in. [3] 
The interrelation of labour costs and research-and-development expenditure can be evaluated with the aid of Student's sample correlation coefficient with $\mathrm{n}$-2 degrees of freedom as exemplified by the enterprise OJSC «Nizhnekamskneftekhim» being the participant of territorial-production cluster in the Republic of Tatarstan.

The relationship between average monthly labour productivity of one workman and research-and-development costs turns out to be positive, as shown in tables 2,3.

Table 2. Data collection.

\begin{tabular}{|l|c|c|c|c|c|c|c|}
\hline Period & 2006 & 2007 & 2008 & 2009 & 2010 & 2011 & 2012 \\
\hline The average monthly labour productivity of one workman, thousand rubbles & 201,7 & 242,5 & 324,7 & 339,1 & 483,1 & 623,1 & 623,7 \\
\hline The total amount of R\&D, thousand rubbles & 320 & 253 & 220 & 165 & 117261 & 193975 & 296009 \\
\hline
\end{tabular}

Table 3. The results.

\begin{tabular}{|c|c|c|c|c|}
\hline Rxy & $\mathrm{n}-2$ & $\mathrm{~T}$ & $\mathrm{a}$ & $\mathrm{t}$ \\
\hline 0,93 & 5 & 5,66 & 0,1 & 2,57 \\
\hline
\end{tabular}

$\mathrm{Rxy}=\sum(\mathrm{Xi}-\mathrm{X}) / \sqrt{ } \sum(\mathrm{Xi}-\mathrm{X})^{\wedge 2} \sum(\mathrm{Yi}-\mathrm{Y})^{\wedge 2}(8)$

$\mathrm{T}=\operatorname{Rxy} \sqrt{ }(\mathrm{n}-2) / \sqrt{ }\left(1-\mathrm{R}^{\wedge 2}\right),(9)$

where

$\mathrm{Xi}$ - the average monthly labour productivity of one workman in thousand rubbles in each period,

$X$ - average of the sum of $X i$ in thousand rubbles,

$Y i$-the total amount of R\&D in thousand rubbles in each period,

$Y$ - average of the sum of $X i$ in thousand rubbles,

Rxy - the sample correlation coefficient,

$T$ - the observed value,

$n$ - quantity of the years.

\section{Conclusions}

The enterprises' innovative development within the frames of a cluster on the territory of regions is capable to ensure:

- the enlargement of enterprise industrial potential;

- build-up of aggregate demand both business and consumer's;

- implementation of the efficient quality system for industrial processes;

- effective utilization of state special purpose funding for investment programs of regions development;

- formation of institutional environment for corporate management as a single process which will make provision for innovative management system implementation.

All the above stated developments can be estimated in the context of such economic indicators as budget increase funded with the cluster participants' return of duties; variation of Gross Regional Product; work places enlargement in the region; increasing the share of investments in intellectual capital at the enterprises -cluster participants; growth in production of final output, goods, works and services.

\section{References}

Argote L., 2013. Organizational learning. Creating, retaining and transfering knowledge., pg. 58.

Boer F., 1999. The valuation of technology business and financial issues in R and D., pg. 72, 77.

Boujelbene M., Affers H., The impact of intellectual capital disclosure on cost of equity capital: a case of French firms., 2013., pg. 46.

Garifova L.F., Kundakchyan R.M., Pratchenko O.V. Integral Estimate of Socio-Ecological-Economic Factors on the Quality of Life of Population of the Region // Mediterranean Journal of Social Sciences. - Vol.5, No12, (2014)-pp. 117 - 121.

Garifova L.F. Tendencies of small business development in the Russian information economy. // Mediterranean Journal of Social Sciences vol. 5 № 24, November 2014, pp. 336-340.

Bounfour A., Edvinsson L., Intellectual capital for communities nations, regions and cities., 2005., pg. 6.

Nagimova, A.M., Safiullina, F.R. (2014). Combination of university training with employment among Kazan' students. Sotsiologicheskie Issledovaniya, (4), pp. 121-124.

Brege S., Nord T., Sjostrom R., Stehn L., Value-added strategies and forward integration in the Swedish sawmill industry: positioning 
and profitability in the high-volume segment., Scandinavian journal of forest research., Vol. 25., pg. 13.

Tsertseil, J.S. The way of clusters uprising and development in the region (By the example of the petrochemical cluster in the republic of Tatarstan). Mediterranean Journal of Social Sciences, Volume 5, Issue 18 SPEC. ISSUE, 2014, Pages 125-128

Safina, D., Podgornaya, A. (2014). Mobbing as an organizational phenomenon impeding implementation of changes. Mediterranean Journal of Social Sciences, 5 (18 SPEC. ISSUE), pp. 187-192

Ray S., Efficacy of economic value added concept in business performance measurement., Advances in information technology and management., Vol. 2., 2012., pg. 262.

Shelby D., Hunt M., The comparative advantage theory of competition., Journal of marketing, Vol. 59., pg. 8.

Huynh T., Gong G., Nguyen A., Integrating activity-based costing with economic value added. Journal of investment and management. Vol. 2.,2013, pg. 34.

Kirshin A.I. Establishing present-day theory of economic growth. Kazan. Kazan State University (KGU) named after V.I. Lenin, 2006., pg. 18.

Kumar S., Phrommathed P., 2005. New product development. An empirical study of the effects of innovation strategy, organization learning and market conditions., pg. 15.

Vishnyakov Ya.D., Kirsanov K.A. , S.P. Kiselyova. Innovation management. Practicum. 2011. 328 p.

Yafizova D.A., Shigabutdinov A.F. Revisiting the issue of the long-run competitiveness of the National Petrochemical Complex/ Life Science Journal 2014;11(8s), pp. 168-171. 